\title{
Seromolecular Prevalence of BEFV Antibodies, Their Correlation with Physiological Biomarkers and Identification of Risk Factors under Field Conditions
}

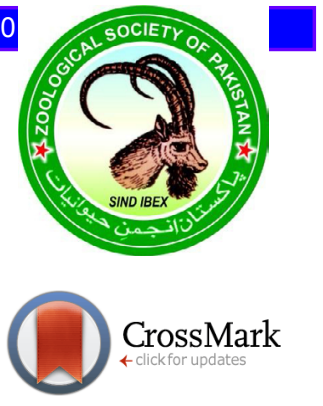

\author{
Muhammad Zahid ${ }^{1}$, Aneela Zameer Durrani ${ }^{1}$, Muhammad Ijaz ${ }^{1}$, Khushi \\ Muhammad $^{1}$, Muhammad Usman ${ }^{1 * *}$, Muhammad Husnain ${ }^{1}$ and Nadeem Kamal ${ }^{2}$ \\ ${ }^{1}$ University of Veterinary and Animal Sciences, Lahore \\ ${ }^{2}$ Livestock and Dairy Development Department, Lahore
}

\begin{abstract}
A B S T R A C T
In the present study, a total of 600 cattle and buffalo were selected from three different topographical locations of Punjab on the basis of clinical biomarkers. Blood and mosquito samples were collected. Blood samples were processed through complement fixation test and RT-PCR, while mosquito samples were processed through RT-PCR. Overall prevalence of bovine ephemeral fever (BEF) in indigenous breeds of bovine was $63.33 \%$, lower, than exotic breeds $64.66 \%$ which were found to be more prone to disease. In the case of buffalo breeds, prevalence was more in Nili Ravi buffalo, i.e. $36.6 \%$ than Kundi breed, i.e. $33.3 \%$. Prevalence of disease was found maximum in humid and plain area of Lahore, i.e. $56 \%$. In dry, dusty and hot weather of Multan overall the prevalence of disease was $55.5 \%$, while in Rajanpur topography of the land is mixed comprising of riverine, plateau, mountainous and semi-hilly areas showed $52.2 \%$ prevalence. When immunity status was taken into account it was found that vaccinated animals showed very low prevalence, i.e. $4.39 \%$ as compared to non-vaccinated animals having $66.53 \%$. Another risk factor age suggested that younger animals were more affected $(60.17 \%)$ as compared to older ones $(29.41 \%)$. It was also observed that animals in closed housing system were more affected as compared to open housed animals. When comparative efficacy of diagnostic tests was done then the results of RT-PCR was found significant $(\mathrm{P}>5)$, than complement fixation test.
\end{abstract}

Article Information
Received 18 May 2018
Revised 12 June 2018
Accepted 10 July 2018
Available online 11 December 2018
Authors' Contribution
MZ cconducted the research.
AZD supervised the study. MI and
KM wew members of supervisory
committee. MU, MH and NK wrote
the manuscript.
Key words
Cattle, BEF, RT-PCR, Punjab,
Complement fixation test.

\section{INTRODUCTION}

A griculture is the lifeline of Pakistan's economy. It has a share of $19.5 \%$ in national GDP while livestock has more than $58 \%$ share in agriculture and cattle and buffalo are integral constituents of livestock. Pakistan has approximately 44.4 million cattle and 37.7 million buffalo population. Pakistan's total gross milk production is 56.08 million ton, while cow and buffalo has a share of 20 and 34 million ton, respectively (GoP, 2016-17).

Bovine ephemeral fever (BEF) has very high economic importance for buffaloes and cattle. The effects of this problem include lower milk production, infertility for little period in males, abortion in sick females, recovery may prolong, problem of transportation and trade of diseased animals. The morbidity may be high up to 80 $\%$ in sick animals while mortality rate becomes $1-2 \%$. The mortality may be higher (30\%) in healthy and fat animals. In BEF affected animals mortality is usually low (1-2\%).

\footnotetext{
Corresponding author: drhmusman@gmail.com 0030-9923/2019/0001-0205 \$ 9.00/0

Copyright 2019 Zoological Society of Pakistan
}

The animals mostly commonly affected seriously with this disease are healthy and having good body score. Most recovered animals develop a solid immunity (Quin et al., 2001).

Geographical distribution of BEF is sporadic in many provinces of Iran, near south and hot areas. The temporal parts of Asian countries on south line like Bangladesh, Pakistan, Iran, and Iraq are the endemic areas of this disease of cattle and buffalo (Roya, 2008). In different hot zones, BEF is commonly subclinical in animals. Outbreaks often follow periods of rainfall. In more temperate regions, epidemics occur during summer months and tend to decline with the onset of winter (Quinn et al., 2001). In Pakistan disease occurs in sporadic form, but in summer 2014 disease was found in exotic and indigenous cattle and water buffaloes. It has severely damaged the dairy industry. The disease was diagnosed on the basis of clinical signs in Pakistan.

BEF is commonly called three-day sickness due to its clinical signs which ends in two or three days. It is an acute, insect borne disease of cattle and water buffalo. This disease is caused by a virus of Ephemerovirus genus in the family Rhabdoviridae. The virus is bullet shaped and has a 
negative single stranded RNA genome with lipid envelope and five structural proteins. There are glycoprotein $G$ containing type specific and neutralizing antigenic sites in its envelope. The transmission is by arthropod vectors. Biting midges, Culicoides oxystoma and C. nipponensis are specific species involved in transmission of the virus (Dhillon et al., 2000). The virus BEFV is the main etiology of acute febrile disease in animals, Bos Taurus, Bos indicus, Bos javanicus and Bubalus bulalis (water buffalo), although BEF virus sub clinically affects a wide variety of polygastric animals (Kato et al., 2009). It causes huge economic losses with decreased milk production, lowering of infertility in males for little period, lameness or paralysis. This disease may be fatal for some animals in different cases (Stram et al., 2005). Other signs of the disease include sudden onset of fever, lameness, stiffness, constipation, cessation of rumination and depression. In BEF milk quality is deteriorated and production is lowered or almost ceased. In natural epizootic, milk production can be reduced up to $12 \%$ of lactation in dairy cattle. Recumbence may be accompanied by salivation and ocular and nasal discharge. Muscular fibrillation and paresis frequently occur, reflecting the accompanying hypocalcaemia (Quin et al., 2001).

BEF virus can spread rapidly and was isolated from different biting insect vectors including species of Culicoides mosquitoes (Stram et al., 2005). The insects get virus with their bite when feeding on blood of animals having brief viremia. The virus, which multiplies in the insect vector, is shed in its saliva and is transmitted to a new host through wounds during feeding. Many of the changes observed in infected animals are attributed to host response rather than to direct viral damage (Quinn et al., 2001).

Keeping in view the above observations this study was designed to evaluate different risk factors for $\mathrm{BEF}$ including species, breed, gender, age, and immunity status along with area wise sero molecular prevalence of bovine ephemeral fever virus. Culicoide mosquitos which are main vectors of the BEFV were also studied and processed for detection of BEFV. The study also incorporated complement fixation test for antigen detection and its results were compared with results of RT-PCR.

\section{MATERIALS AND METHOD}

\section{Geo-location of study area}

The present study was carried out in three different topographical regions (having different climatic conditions) of Punjab province viz. Lahore, Multan and Rajanpur. Punjab lies between $31.1471^{\circ} \mathrm{N}$ and $75.3412^{\circ} \mathrm{E}$. From late June till August, the monsoon seasons starts, with heavy rainfall throughout the province. Lahore is located in the northern part of Punjab and consists of plain area with humid weather. Multan features an arid weather (Koppen climate classification BWh) with mild winters and very hot summers with dusty storms. District Rajanpur is located in the southern part of the Punjab; topography of the land is mixed comprising of riverine, plateau, mountainous and semi-hilly areas. The average temperature during summer months may rise up to $52{ }^{\circ} \mathrm{C}$ and $40-48{ }^{\circ} \mathrm{C}$, in Rajanpur and Lahore districts, respectively, while highest recorded temperature in Multan is $54{ }^{\circ} \mathrm{C}$. The average annual rainfall is $7.08 \mathrm{~mm}, 186 \mathrm{~mm}$ and $628.8 \mathrm{~mm}$ in Rajanpur, Multan and Lahore, respectively.

\section{Source of animals}

To find out the epidemiology and risk factors of bovine ephemeral fever, dairy cattle and buffaloes from corporate dairy farms and small holder dairy farmers were used in this study. Total of 600 dairy animals ( $n=200$ from each district) showing clinical manifestations of bovine ephemeral fever were selected and subjected to Disease Diagnosis Lab, Rajanpur. Data about each animal was collected in survey about species, breed, sex, age, physiological status, lactation status, housing type, feeding, previous history of diseases, vaccination status, morbidity, mortality etc. After clinical examination of animals blood samples were collected from animals suffering from BEF (Durrani, 2007):

Number of cases of disease present in the population at a specified time / Total population at that specified time period and in the same geographical area

\section{Collection of blood samples}

Ten $\mathrm{mL}$ of blood sample was collected from each animal from the jugular vein using hypodermic 1.5 " $\mathrm{x} 18 \mathrm{G}$ needle attaché to disposable syringe for sero-prevalence and serum chemistry. The blood samples were poured into plain vacutainers and were allowed to clot. After clotting, the samples were centrifuged at $3500 \mathrm{rpm}$ for $5 \mathrm{~min}$ and serum was collected into Eppendorf tube by Pasteur pipette. The serum samples were stored at $-20^{\circ} \mathrm{C}$ till further analysis. Mosquitoes from study area were collected for detection of virus by netting.

\section{Analysis of serum samples}

Serum samples collected from 80 BEF suspected positive cattle and were analyzed using reverse transcriptase Polymerase Chain Reaction for the confirmation of BEF. The procedure used by Thabet et al. (2011) was followed. Forward and reverse primers used for detection of BEF virus in serum samples (Slomka et al., 2009) are: forward primer FG 5, 
-TATTACCCTCCTGCCGGATGCTTT-3' and Reverse primer RG 5' -AGGTCTGTATTCGCACCAAGCTCT-3'. The conditions used for denaturation, annealing and extension were $95^{\circ} \mathrm{C}, 56^{\circ} \mathrm{C}$ and $72^{\circ} \mathrm{C}$ for 30,1 and $1 \mathrm{~min}$, respectively. While $32{ }^{\circ} \mathrm{C}$ temperature for $10 \mathrm{~min}$ was used for final extension and overall 35 cycles were used.

RNA was extracted using TRIzol (Invitrogen, Carlsbad, CA USA) from solution according to the manufacturer's description. For reverse transcription (RT) reaction was carried out using a cDNA synthesis kit (\#K1622 Thermo Scientific Revert Aid First standard cDNA Synthesis Kit) following the manufacturer's instructions.

\section{Detection of BEF virus from mosquitoes}

Mosquitoes were captured from the dairy sheds and houses in which BEF affected animals were present. The mosquitoes were dissected and the virus was detected using method adopted by Plichart et al. (2006). In this method collected mosquitoes were dissected and intestinal material was processed for polymerase chain reaction as described above.

\section{RESULTS}

\section{Prevalence}

Prevalence of BEFV was checked using reverse transcriptase PCR and results showed that its maximum prevalence was in 68 and $44 \%$ in samples collected from cattle and buffaloes of district Lahore as showed in Table I. While morbidity and mortality of BEFV in districts Rajanpur, Multan and Lahore were 99.04 and $0.95 \%, 99.09$ and $0.90 \%$, and 98.38 and $1.61 \%$, respectively (Table I). These values suggested that its morbidity was very high and mortality was almost negligible in all districts.

Table I.- Overall prevalence of BEF.

\begin{tabular}{lcccccccc}
\hline Samples & \multicolumn{2}{c}{ Lahore } & & \multicolumn{2}{c}{ Multan } & & \multicolumn{2}{c}{ Rajanpur } \\
\cline { 2 - 3 } & Cattle & Buffalo & & Cattle & Buffalon & & Cattle & Buffalo \\
\hline Positive & 102 & 22 & & 95 & 16 & & 90 & 15 \\
& $(68 \%)$ & $(44 \%)$ & & $(63.3 \%)$ & $(32 \%)$ & & $(60 \%)$ & $(30 \%)$ \\
Negative & 48 & 28 & & 55 & 34 & & 60 & 35 \\
& $(32 \%)$ & $(66 \%)$ & & $(36.3 \%)$ & $(68 \%)$ & & $(40 \%)$ & $(70 \%)$ \\
Total & 150 & 50 & & 150 & 50 & & 150 & 50 \\
\hline
\end{tabular}

\section{Risk factors}

It was recorded that there was variation in the prevalence of disease when various risk factors were considered. The disease was more prevalent in cattle, i.e., $69.33 \%$ than in buffaloes of Pakistan as shown in Figure 1. While breed wise data suggested that exotic breed of cattle is more prone to BEF as compared to local breeds of Pakistan. In the case of buffalo, the breed Nili Ravi was more affected than Kundi breed (Table II). Third risk factor age suggested that usually animals less than 6 months' age were not affected. The animals of age group 1 to 2 years were more affected as shown in Figure 2. When immunity status of animals is considered it was found that mostly non vaccinated animals were positive for disease. Although, some vaccinated animals were also suffering but of negligible ratio, i.e., $4.39 \%$ as compared to nonvaccinated. The morbidity and mortality in these animals were given in Table II.

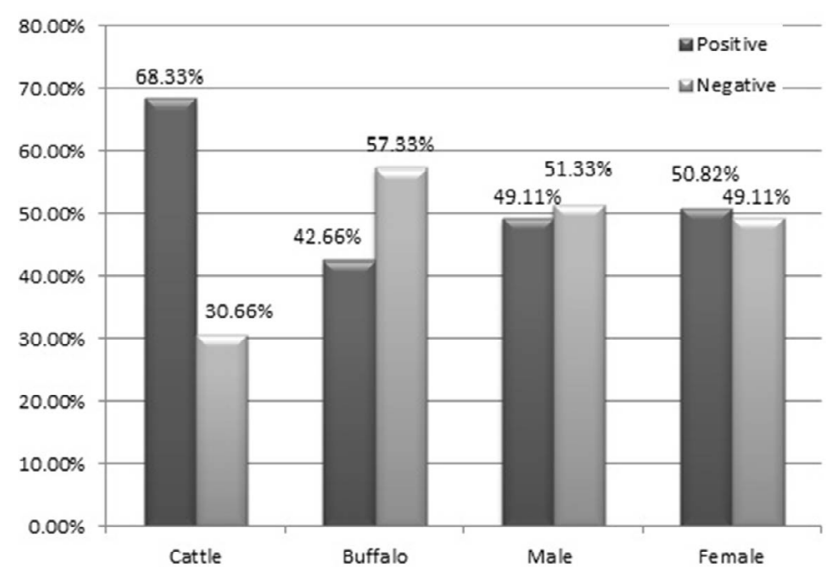

Fig. 1. Species and gender susceptibility of BEF in Punjab.

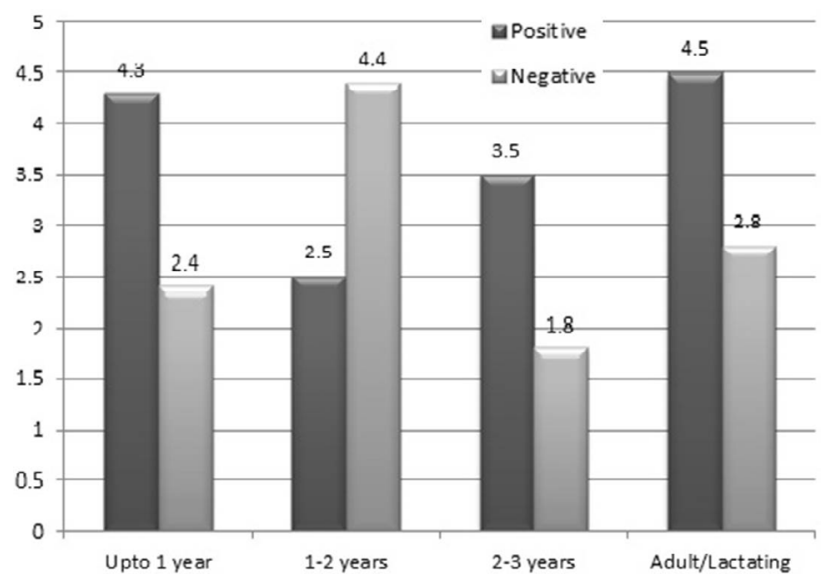

Fig. 2. Age susceptibility of BEF in bovines of Punjab.

Results of RT-PCR and complement fixation test (CFT)

Samples were collected from those animals which were showing clinical signs of BEF. The results RT-PCR and CFT are given in Table III. Results of RT-PCR are significant with $0.352 \mathrm{P}$ value. There was no band against marker on agarose gel electrophoresis, when mosquito's samples were processed for PCR. 
Table II.- Breed and immunity status.

\begin{tabular}{|c|c|c|c|c|c|c|c|c|}
\hline \multirow[t]{2}{*}{ Sample } & \multicolumn{4}{|c|}{ Breed } & \multicolumn{4}{|c|}{ Immunity status } \\
\hline & Cattle local & Cattle exotic & Buff Nili Ravi & Buff Kundi & $\begin{array}{l}\text { Previous } \\
\text { exposure }\end{array}$ & $\begin{array}{c}\text { First } \\
\text { exposure }\end{array}$ & $\begin{array}{c}\text { Non- } \\
\text { vaccinated }\end{array}$ & Vaccinated \\
\hline Positive & $190(63.33 \%)$ & $97(64.66 \%)$ & $33(36.6 \%)$ & $20(33.3 \%)$ & $1(4.76 \%)$ & $339(58.54 \%)$ & $336(66.53 \%)$ & $4(4.39 \%)$ \\
\hline Negative & $110(36.66 \%)$ & $53(35.33 \%)$ & $57(63.3 \%)$ & $40(66.33 \%)$ & $20(95.23 \%)$ & $240(41.45 \%)$ & $169(33.46 \%)$ & $91(95.78 \%)$ \\
\hline Total & 300 & 150 & 90 & 60 & & & & \\
\hline
\end{tabular}

Table III.- Results of RT-PCR and complement fixation test.

\begin{tabular}{|c|c|c|c|c|c|}
\hline \multirow[t]{2}{*}{ District } & \multicolumn{2}{|c|}{ Results of RT-PCR } & \multicolumn{2}{|c|}{ Results of CFT } & \multirow{2}{*}{$\begin{array}{c}\text { False } \\
\text { Pos / Neg }\end{array}$} \\
\hline & Positive & Negative & Positive & Negative & \\
\hline & & $\begin{array}{c}76 \\
(32 \%)\end{array}$ & & $\begin{array}{c}44 \\
(32 \%)\end{array}$ & $\begin{array}{c}40 \\
(20 \%)\end{array}$ \\
\hline & $\begin{array}{c}111 \\
(55.5 \%)\end{array}$ & $\begin{array}{c}89 \\
(44.5 \%)\end{array}$ & $\begin{array}{c}96 \\
(48 \%)\end{array}$ & $\begin{array}{c}84 \\
(42 \%)\end{array}$ & $\begin{array}{c}20 \\
(10 \%)\end{array}$ \\
\hline $\begin{array}{l}\text { Rajanpur } \\
(n=200)\end{array}$ & $\begin{array}{c}105 \\
(52.5 \%)\end{array}$ & $\begin{array}{c}95 \\
(47.5 \%)\end{array}$ & $\begin{array}{c}94 \\
(47 \%)\end{array}$ & $\begin{array}{c}88 \\
(44 \%)\end{array}$ & $\begin{array}{c}18 \\
(9 \%)\end{array}$ \\
\hline $\begin{array}{l}\text { Total } \\
(\mathrm{n}=600)\end{array}$ & $\begin{array}{c}340 \\
(56.7 \%)\end{array}$ & $\begin{array}{c}260 \\
(43.3)\end{array}$ & $\begin{array}{c}306 \\
(51 \%)\end{array}$ & $\begin{array}{c}216 \\
(36 \%)\end{array}$ & $\begin{array}{c}78 \\
(13 \%)\end{array}$ \\
\hline
\end{tabular}

\section{DISCUSSION}

In this study three districts of Pakistan were target areas and six hundred (200 each district) samples were collected from cattle and buffaloes. Prevalence and risk factors were studied in the target areas. Samples were collected from the animals showing clinical signs of bovine ephemeral fever. The disease was diagnosed and confirmed by RT-PCR. Study by Momtaz et al. (2012) who reported the prevalence of disease in cattle was $29 \%$ while $17 \%$ in buffaloes. In this rationale this study was conducted and observed the prevalence. In Rajanpur district, the prevalence of disease in cattle was $60 \%$ and $30 \%$ in buffaloes while in district Multan the percentage was $63.3 \%$ and $32 \%$ in cattle and buffaloes, respectively. In Lahore district, the observed prevalence in cattle was $68 \%$ while $44 \%$ in buffaloes. It was recorded that BEF was more prevalent in cattle than buffaloes in all three districts of study. Zaher and Ahmed (2011) reported that generally the signs of BEF were more frequent in cattle than buffaloes. These arguments are similar with results of this study. There is possibility that buffaloes have hard skin than that of cattle and probability buffaloes are less harassed by mosquitoes than cattle. These results coincide with the observations recorded by Momtaz et al. (2012), who also described that there is possibility that buffaloes are less harassed by insects and BEF is in low ration in this species. There was a significant difference of disease between females and males. BEF was more prevalent in females $(75.21 \%)$ than males $(61.85 \%)$ in both species of cattle and buffaloes. Same type of pattern of disease in females and males was observed by Momtaz et al. (2012). In another study, Al-Sultany and Hassan (2013) also recorded the same observations that disease was significantly more frequent in females (14\%) and less frequent in males $(10 \%)$. In this study prevalence of disease was found more in young animals $(66.6 \%)$ than in old animals (29.41\%). Such type of observations may be indicating that mature animals are more resistant to the diseases than young animals. It was also recorded that the mostly healthy cattle and buffaloes were suffered BEF. These results have similarity with the observations recorded by Zaher and Ahmed (2011). While Momtaz et al. (2012) and Al-Sultany and Hassan (2013) reprted that disease was less prevalent in younger and more frequent in older animals probably because older animals are less frequently stung by the vectors. Lactating animals were more resistant to the disease than non-lactating.

During this field study it was seen that more animals in closed housing system were facing the problem of disease than the animals in open housing system. It may be due to the more temperature and humidity. There is also possibility that the tied animals are more exposed to the mosquitoes and other biting insects than those animals in open housing system. It was recorded that BEF outbreak was observed in early autumn, after heavy rainfall in summer. The study conducted in Taiwan by Liao' et al. (1998) also reported the same findings. This might be due to increase in population of disease vectors (mosquitoes and midges) in rainy season, as rainfall favors such increase in these vectors. It was also noted during the study that mostly animals $58.54 \%$ were first time exposed to $\mathrm{BEF}$, while $4.76 \%$ animals were suffered BEF second time in their life. The morbidity rate observed in this study was almost $99 \%$ while mortality rate was almost negligible in all districts. These results are correlated with those of Farag et al. (1998) who conducted a study in Saudi Arabia and published $0.3 \%$ and $0.6 \%$ mortality while morbidity $5 \%$ to $61 \%$ in affected herds at a dairy 
farm. Another such type of observations were recorded in a study by Yeruham et al (2010), who reported $78.4 \%$, $97.7 \%$ and $100 \%$ herd incidences in 1990, 1999 and 2004. In their study it was reported that morbidity was $20 \%$, $38.6 \%$ and $22.2 \%$, while case fatality rate was $2 \%, 8.6 \%$ and $5.4 \%$, respectively in the described particular era of time. They hypothesized that mosquitoes of Culicoides spp. are vectors of BEF virus in Israel. These results are correlated with our study. Some differences may be due to any variation of climate. In this study it was recorded that $4.93 \%$ animals were found positive for BEF. It was astonishing and may be hypothesized that booster dose was not given. Unfortunately we could not find such type of study that may be correlated to these results. The outbreak of BEF occurred at some commercial dairy farms on which animals were vaccinated. Live attenuated vaccine was used on those dairy farms. Cybinski et al. (1992), reported that there are 5 antigenic sites $(01,02$, 03a, 03b and 04) identified on the glycosylated envelop protein of BEF virus. Subunit vaccines are needed to be used with incorporation with more than one glycoprotein for elicitation of response of complete T-Lymphocyte. It may be possibility of vaccination failure. No further study was performed to test the antibody titer of such animals.

Diagnostic confirmation of disease from samples, obtained from clinically affected animals, was done by RT-PCR in this study. It was recorded that in Lahore, $62 \%$ samples were positive, while $55.5 \%$ and $52.5 \%$ were found positive in Multan and Rajanpur, respectively. Many other scientists like Thabet et al. (2011) and Bakhshesh and Abdollahi (2014) also obtained samples from clinically affected animals and confirmed the positive cases in bovines. Such type of study was also described by Zaher and Ahmed (2011), who reported that there were 40 $(66.67 \%)$ positive cases out of 60 cattle. They found these results after confirmation of BEF virus through RT-PCR in samples of diseased cattle. Degheidy et al. (2011) collected 95 samples from BEF affected bovines and separated buffy coat from blood samples and found $17.8 \%$ positive samples after amplification of RT-PCR. In a study by Finlaison et al. (2014), it was recorded that almost $69 \%$ positive samples were found positive after diagnosis through Rt-PCR. These all results are similar because they also amplified the $G$ gene after cDNA production from RNA of the same virus. Al-Sultany and Hassan (2013) collected 150 samples from BEF affected animals in different locations of Babylon Province. The positive cases of BEF were reported with percentage of 24.4 with significant $(\mathrm{P}<0.05)$ results. They also reported various frequencies of cases from different locations. In their study it was reported that $16.66 \%$ cases in Al-Qasim Municipality, $14.28 \%$ in Al-Hashemia, while $30.10 \%$ positive cases were diagnosed in A-Madhatia
Municipalities. It shows the different percentage of BEF infection in same province but within different location of country. Some differences between the percentages of infection may be climatic change, species, geo-location and breed differences. This study in Pakistan is almost first study on doctoral level.

In this study all samples were also confirmed by compliment fixation test. It was found that 58\%, 48\%, 47\% positive samples were found from Lahore, Multan and Rajanpur districts, respectively, while $20 \%, 10 \%$ and $9 \%$ samples were found either false positive or false negative in the same areas. These findings confirmed that RT-PCR is more reliable in detecting BEFV than complement fixation test.

\section{CONCLUSION}

It is concluded from the above discussion that bovine ephemeral fever is an emerging vector-borne viral disease in bovines. There is a need to prioritize further study and develop BEFV vaccine for saving future economic losses.

\section{ACKNOWLEDGEMENT}

This research was supported by PAK-US project 'Capacity building of neglected vector-borne diseases of livestock'.

Statement of conflict of interest

Authors have declared no conflict of interest.

\section{REFERENCES}

Al-Sultany, O.H.H. and Hassan, I.Q., 2013. Molecular investigation of bovine ephemeral fever in Iraq. Mirror Res. Vet. Sci. Anim., 2: 43-51.

Bakhshesh, M. and Abdollahi, D., 2014. Bovine ephemeral fever in Iran: Diagnosis, isolation and molecular characterization. J. Arthropod Borne Dis., 9: 195.

Cybinski, D.H., Davis, S.S. and Zakrzewski, H., 1992. Antigenic variation of the bovine ephemeral fever virus glycoprotein. Arch. Virol., 124: 211-224. https://doi.org/10.1007/BF01309803

Degheidy, N.S., Hassan, H.Y., El-Sanousi, A.A., Salem, S.A., Beshir, E. and ElSadawy, H.A., 2011. Recent trails for diagnosis of bovine ephemeral fever in Egypt. In: Animal hygiene and sustainable livestock production (eds. J. Kofer and H. Schobesberger). Proceeding of the $\mathrm{XV}^{\text {th }}$ International Congress of the International Society for Animal Hygiene, Vienna, Austria, pp. 447-451.

Dhillon, J.J., Cowley, A., Wang, Y. and Walker, P.J., 
2000. RNA Polymerase (L) gene and genome terminal sequence of ephemeroviruses bovine ephemeral virus and Adelaide river virus indicate a clise relationship to vesiculovirus. Virus Res., 70: 87-95. https://doi.org/10.1016/S01681702(00)00215-X

Durrani, A.Z., 2007. Epidemiology, serodiagnosis and chemoprophylaxis of theileriosis in cattle. $\mathrm{PhD}$ thesis, University of Veterinary and Animal Sciences, Lahore, Pakistan. Available at: http://opac.uvas.edu.pk/cgi-bin/koha/ opac-detail.pl?biblionumber $=2753 \&$ query desc $=\mathrm{kw} \% 2 \mathrm{Cwrdl} \% 3 \mathrm{~A} \% 20$ durrani (accessed 10 April 2018).

GoP, 2016-17. Economic survey of Pakistan. Available at: http://www.finance.gov.pk/survey_1617.html (Accessed 08 April 2018)

Farag, M.A., al-Sukayran, A., Mazloum, K.S. and Al-Bukomy, A.M., 1998. Epizootics of bovine ephemeral fever on dairy farms in Saudi Arabia. Rev. Sci. Tech., 17: 713-722. https://doi.org/10.20506/ rst.17.3.1127

Finlaison, D., Read, A., Zhang, J., Paskin, R. and Kirkland, P., 2014. Application of real time polymerase chain reaction assay to the diagnosis of bovine ephemeral fever during an outbreak in New South Wales and Northern Victoria in 200910. Aust. Vet. J., 92: 24-27. https://doi.org/10.1111/ avj.12139

Kato, T., Aizawa, M., Takayoshi, K., Kokuba, T., Yanase, T., Shirafuji, H., Tsuda, T. and Yamakawa, M., 2009. Phylogenetic relationships of the $\mathrm{G}$ gene sequence of bovine ephemeral fever virus isolated in Japan, Taiwan and Australia. Vet. Microbiol., 137: 217223. https://doi.org/10.1016/j.vetmic.2009.01.021

Liao, Y., Inaba, Y., Li, N., Chain, C., Lee, S. and Liou, P., 1998. Epidemiology of bovine ephemeral fever virus infection in Taiwan. Microbiol. Res., 153: 289-295. https://doi.org/10.1016/S09445013(98)80014-1

Momtaz, H., Nejat, S., Moazeni, M. and Riahi, M., 2012. Molecular epidemiology of bovine ephemeral fever virus in cattle and buffaloes in Iran. Rev. Med. Vet., 163: 415-418.

Plichart, C., Sechan, Y., Davies, N. andAnne-Marie, L., 2006. PCR and dissection as tools to monitor filarial infection of Aedes polynesiensis mosquitoes in French Polynesia. Filaria J., 5: 2. https://doi. org/10.1186/1475-2883-5-2

Quinn, P.J., Markey, B.K., Carter, M.E., Donnelly, W.J. and Leonard, F.C., 2001. Veterinary microbiology and microbial disease. Wiley-Blackwell, pp. 394395.

Roya, S., 2008. Survey on serological diagnosis of bovine ephemeral fever (BEF) by IR-BK and Vero cell lines in Southern provinces of Iran by in vitro methods. $15^{\text {th }}$ congress of FAVA, Bangkok, Thailand, pp. 267-268.

Slomka, M.J., Theo, P., Coward, V.J., John, V., Koch, G.K., Amanda, H., Jill, B. and Brown, I.H., 2009. Validated real time reverse transcriptase PCR methods for the diagnosis and pathotyping of Eurasian $\mathrm{H} 7$ avian influenza viruses. Influ. Oth. Respir. Virus., 3: 151-164. https://doi.org/10.1111/ j.1750-2659.2009.00083.X

Stram, Y., Kuznetzova, L., Levin, A., Yadin, H. and Rubinsteingiuni, M., 2005. A real-time RT quantative PCR for the detection of bovine ephemeral fever virus. J. Virol. Meth., 130: 1-6. https://doi.org/10.1016/j.jviromet.2005.05.024

Thabet, N.S., Ghazy, E.W., Nayel, M.A. and Elkhair, M.A., 2011. Molecular and biochemical studieson bovine ephemeral fever. Res. Opin. Anim. Vet. Sci., 1: 269-275.

Yeruham, I., Michael, V., Ham-Yehuda, S., Orly, F., Hagai, Y., Kosta, Y. and Mumcuoglu-Yehuda, B., 2010. Epidemiological investigation of bovine ephemeral fever outbreaks in Israel Vet. Med. Int., 2010: Article ID 290541. doi: 10.4061/290541

Zaher, K.S. and Ahmed, M.W., 2011. Investigation of bovine ephemeral fever virus in Egyptian cows and buffaloes with emphasis on isolation and identification of field strain. Glob. Vet., 6: 447-452. 